Rathi $R$ K and Revathi R. / International Journal of Research in Pharmaceutical and Nano Sciences. 9(2), 2020, 39-45.

Review Article

CODEN: IJRPJK

ISSN: $2319-9563$

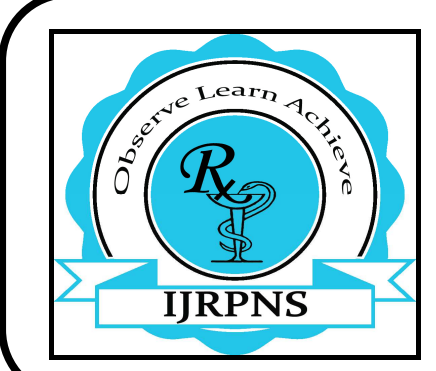

\title{
International Journal of Research
} in

Pharmaceutical and Nano Sciences

Journal homepage: www.ijprpns.com

https://doi.org/10.36673/IJRPNS.2020.v09.i02.A07

\section{ASSESSMENT OF KNOWLEDGE AND PERCEPTION TOWARDS COVID-19 AMONG PEOPLE LIVING IN AND AROUND MADURAI}

\author{
R. K. Rathi" ${ }^{* 1}$ and R. Revathi ${ }^{1}$ \\ 1*Velammal School and College of Nursing, Madurai, Tamil Nadu, India.
}

\begin{abstract}
\section{KEYWORDS}

COVID-19, Coronavirus disease, Knowledge and Perception.
\end{abstract}

Novel coronavirus (nCoV) is a new type of virus that has not been previously identified in humans. It is an infectious disease that causes illness ranging from common cold to severe respiratory illness. The objective of this study is to assess the level of knowledge and perception among the people living in and around Madurai. A descriptive study design was used in this study. Data were collected with structured validated questionnaire on knowledge and it was sent through emails, WhatsApp to collect the data from participants. Participation of this study was voluntary. Descriptive analysis was used to find out the, mean knowledge and perception scores. A total of 149 participants have participated in the study and the result shows that a mean knowledge score and mean perception score of $8.18 \pm 1.28$ and $2.35 \pm 0.91$ respectively. The overall responses to this study were good. The participants of this study possess good knowledge about COVID-19 and moderate level of perception. $81.2 \%$ of participants have agreed for self isolation if they have any symptoms of COVID-19, 76.5\% of participants have agreed to have vaccination, if available and $6.71 \%$ of participants were uncertain about isolating themselves if they have any symptoms of COVID19. 54.3\% of participants are receiving information regarding COVID-19 through television. People had almost good knowledge about COVID-19. Creating awareness through media may encourage them to develop optimistic attitudes and maintain safe practices. Hopefully our government efforts jointly make us to win the battle of COVID-19 in upcoming days.

\section{Author for Correspondence:}

Rathi R K,

Velammal School and College of Nursing,

Madurai, Tamil Nadu, India.

Email: rathimadhavrk@gmail.com

Available online: www.uptodateresearchpublication.com

\section{INTRODUCTION}

COVID-19 (Coronavirus disease 2019) ${ }^{1}$ is a type of common virus that infects humans as well as animals. It is an infectious disease caused by a newly discovered corona virus. Corona virus is derived from Latin word "corona". In ancient language corona means "crown". Historically

March - April 39 
Rathi $R$ K and Revathi R. / International Journal of Research in Pharmaceutical and Nano Sciences. 9(2), 2020, 39-45.

evidence has shown that the virus is transmitted through birds and mammals, with humans being particularly vulnerable to infection and transmission of the virus. The new corona virus is a respiratory virus which spreads through the droplets. The previous outbreaks of coronaviruses were found in the form of Severe Acute Respiratory SyndromeCoronavirus (SARS-CoV) in 2003 and Middle East Respiratory Syndrome-Coronavirus (MERS-CoV) in 2015. This is how the similarities to the novel coronavirus, the source of covid-19 first started in Wuhan, China. The World Health Organization officially declared the COVID-19 as a pandemic on $11^{\text {th }}$ March 2020 as 144 countries are affected with more than 120,000 cases worldwide. The spread of novel coronavirus in India has quickened for the past few days with new cases of coronavirus and COVID-19 deaths being reported every day. After the first confirmed positive case was reported on January 30 in Kerala, the epidemic has expanded its footprints in the country, affecting more than 20,000 people. Total cases in India spikes to 21,700; death toll at 686 and in Tamilnadu it spikes to 1629 and reported death rate is 18 as on $23^{\text {rd }}$ April 2020.

\section{Need and Significance of the study}

More than three billion people around the world have been living under lockdown for the past few days as governments step up efforts to combat corona virus pandemic which has left more than 1.65 lakh of people died globally. World Health Organization (March 2020) ${ }^{2}$ reported that the COVID-19 spreads by human-to-human through droplets, feco-oral route and direct contact, with an incubation period of 2-14 days. So far, no antiviral treatment or vaccine has been recommended explicitly for COVID-19. Therefore, applying the preventive measure to control COVID-19 infection is the utmost critical intervention. Recommended measures to prevent infection include washing hands with soap and water for 20 seconds, maintaining social distancing from others and especially from those with symptoms, wearing mask while going out, cover the mouth, nose while cough and sneeze with tissue paper and keeping

Available online: www.uptodateresearchpublication.com unwashed hands away from the face are recommended for those who suspect to have symptoms and their caregivers. Therefore, the general focus of this research is to assess the knowledge and perception towards COVID-19 among people living in and around Madurai to organize awareness programs and deliver the best practice to control COVID-19.

\section{Review of Literature}

Kumar Dharmendra, et al, (2020) $)^{3}$ investigated and reported that corona virus causes respiratory tract infection including pneumonia, cold, sneezing and coughing and transmitted from human to human or human to animal via airborne droplets. Corona virus gets into human cell through membrane ACE-2 exopeptidase receptor. World Health Organization (WHO) and Centers for Disease Control and Prevention (CDC) advised to avoid public place and avoid close contact with infected persons and pet animals.

Akshaya Srikanth Bhagavathula, et al, (2020) conducted a cross-sectional, web-based study aimed to investigate the knowledge and perceptions of Health Care Workers (HCW) about COVID-19 during the first week of March 2020. Investigator developed a survey instrument and distributed randomly to HCWs using social media. Chisquare test was used to analyze the level of association among variables at the significance level of $p<0.05$. A total of $453 \mathrm{HCW}$ s completed the survey. $51.6 \%$ are males, aged $25-34$ years $(32.1 \%)$, and most of them are doctors (30.2\%) and medical students (29.6\%). Regarding COVID-19, most of them used social media to obtain the information (61\%). Investigator concluded that a significant proportion of HCWs had poor knowledge of its transmission (61\%), and symptoms onset $(63.6 \%)$ and showed a positive perception of COVID-19 prevention and control. Factors such as age and profession are associated with inadequate knowledge and poor perception of COVID-19.

Deblina Roy, et al, $(2020)^{5}$ done a study of knowledge, attitude, anxiety and perceived mental healthcare need in Indian population about COVID19. Their result shows more than $80 \%$ of people March - April 40 
Rathi $R$ K and Revathi R. / International Journal of Research in Pharmaceutical and Nano Sciences. 9(2), 2020, 39-45.

were preoccupied with the thoughts of COVID-19 and $72 \%$ reported the need to use gloves and sanitizers. Investigator concluded that the responders had a moderate level of knowledge about COVID-19 infection, adequate knowledge about its preventive measures and having positive attitudes to follow government guidelines on quarantine and social distancing.

\section{Statement of the problem}

A descriptive study to assess the knowledge and perception regarding COVID-19 among people living in and around Madurai

\section{Objectives}

- To assess the level of knowledge and perception regarding COVID-19 among people living in and around Madurai

- To associate the level of knowledge and perception with selected demographic variables

\section{METHODOLOGY}

A descriptive design was used in this study. A structured questionnaire is prepared in English and Tamil, and it was sent through emails and WhatsApp to the contacts of the investigators for collecting data. The participants were encouraged to fill the questionnaire and sent back to the investigator. Participation of this study was voluntary, a total of 149 responses were received and recorded.

\section{Inclusion Criteria}

Age more than 18 years

Able to understand Tamil and English

Willing to give informed consent

Participants with access to the internet and smartphones.

\section{Data collection}

A structured questionnaire included three parts. Part I comprised of demographic variables of the participants such as age, gender, marital status, education, occupation and source of information about COVID-19. Part II included 10 multiple choice questions regarding the knowledge of COVID-19 and developed by the investigator based on the information and recommendations given by Available online: www.uptodateresearchpublication.com the World Health Organization. The knowledge score ranged from 0 to 10 . A score of $<4$ interpreted as poor knowledge, score of 5 to 7 interpreted as adequate knowledge and a score of 7 to 10 interpreted as good knowledge about COVID19. Part III included 4 statements regarding the perception of COVID-19. Participants were asked to indicate their level of agreement using a three point likert scale ranging from agree, uncertain and disagree.

\section{Data analysis}

Descriptive statistics were used to analyze the findings. Results were reported as frequency, percentage, mean scores and standard deviation. Chi square tests were used to associate the level of knowledge and perception with demographic variables such as age, gender, marital status, education, occupation and source of information about COVID-19.

\section{RESULTS}

\section{Section A - Demographic Variables}

Table No.1 depicts that $57.7 \%$ of participants belong to age between 18 to 30 years, $75.8 \%$ of participants were females, $50.3 \%$ of participants were married, $44.9 \%$ of the participants have completed undergraduate programme, $54.3 \%$ of participants have received COVID-19 information through television.

Section B - Knowledge of COVID-19 among people living in and around Madurai

Table No. 2 depicts that $96.6 \%$ of participants were aware of the preventive measures to safeguard themselves by maintaining social distancing, 95.9\% of participants know about washing hands with soap and water for 20 seconds will help them to keep away from COVID-19, 93.9\% of Participants know to discard the used mask in closed dustbins, $91.9 \%$ of participants know the symptoms and preventive measures of COVID-19. The overall responses to this study were good. $69.8 \%$ of participants have good knowledge regarding COVID-19.

March - April

41 
Rathi $R$ K and Revathi R. / International Journal of Research in Pharmaceutical and Nano Sciences. 9(2), 2020, 39-45.

Section C - Perception towards COVID-19 among people living in and around Madurai

Table No.3 depicts distribution of perception of COVID-19 among people living in and around Madurai. $44.2 \%$ of participants have disagreed for the statement that they may not get illness in this season and $12 \%$ of the participants have disagreed to isolate themselves if they get COVID-19. $81.2 \%$ of participants have agreed to isolate themselves if they get COVID-19, 76.5\% of participants are willing to vaccinate if vaccine is available and $6.71 \%$ of participants were uncertain about isolating themselves if they get COVID-19.

Section D - Association of Knowledge scores with demographic variables

Table No.4 shows the association of demographic characteristics and knowledge scores towards COVID-19. In association with education (.003446), occupation (.017038) and source of information about COVID-19 (.000357) were significant at .05 levels.
Section D - Association of perception scores with demographic variables

Table No.5 shows the association of democratic characteristics and perception towards COVID-19 in which age (.015071) was significant and education, occupation, are not significant at .05 level.

\section{DISCUSSION}

The findings of this study showed peoples living in and around Madurai had high level of knowledge and moderate level of perception towards the COVID-19 outbreak. Majority of the participants know that COVID-19 is an infectious disease and they are gathering information through television $(54.3 \%)$ and social media (41.6\%). They are also aware that no vaccines and specific treatment are available to treat the COVID-19 and it can be prevented by maintaining social distancing, washing hands with soap and water and wearing mask.

Table No.1: Frequency and Percentage distribution of Demographic variables $(\mathrm{N}=149)$

\begin{tabular}{|c|c|c|c|}
\hline S.No & Variables & Frequency $(n=149)$ & Percentage $(\%)$ \\
\hline \multicolumn{4}{|c|}{ Age in years } \\
\hline 1 & 18 to 30 & 86 & 57.7 \\
\hline 2 & 31 to 50 & 50 & 33.5 \\
\hline 3 & $>51$ & 13 & 8.7 \\
\hline \multicolumn{4}{|c|}{ Gender } \\
\hline 4 & Male & 36 & 24.1 \\
\hline 5 & Female & 113 & 75.8 \\
\hline \multicolumn{4}{|c|}{ Marital status } \\
\hline 6 & Married & 72 & 48.3 \\
\hline 7 & Unmarried & 75 & 50.3 \\
\hline 8 & Others (widowed) & 2 & 1.3 \\
\hline \multicolumn{4}{|c|}{ Education } \\
\hline 9 & Illiterate & 12 & 8.0 \\
\hline 10 & School education & 56 & 37.5 \\
\hline 11 & Undergraduate & 67 & 44.9 \\
\hline 12 & Postgraduate & 14 & 9.3 \\
\hline \multicolumn{4}{|c|}{ Occupation } \\
\hline 13 & Unemployed & 36 & 24.1 \\
\hline 14 & Employed & 48 & 32.2 \\
\hline 15 & Students & 65 & 43.6 \\
\hline \multicolumn{4}{|c|}{ Source of COVID-19 information } \\
\hline 16 & Television & 81 & 54.3 \\
\hline 17 & Social media (WhatsApp, Facebook) & 62 & 41.6 \\
\hline 18 & Friends/relatives & 6 & 4.0 \\
\hline
\end{tabular}

Available online: www.uptodateresearchpublication.com March - April 
Rathi R K and Revathi R. / International Journal of Research in Pharmaceutical and Nano Sciences. 9(2), 2020, 39-45.

Table No.2: Frequency and Percentage distribution of Knowledge regarding COVID19 among people living in and around Madurai $(\mathrm{N}=149)$

\begin{tabular}{|c|c|c|c|}
\hline \multirow{2}{*}{ S.No } & Knowledge questionnaire & \multicolumn{2}{c|}{ Correct answers } \\
\cline { 3 - 4 } & & $\begin{array}{c}\text { Frequency } \\
(\mathbf{n}=\mathbf{1 4 9})\end{array}$ & $\begin{array}{c}\text { Percentage } \\
(\%)\end{array}$ \\
\hline 1 & What is Novel Corona virus & 128 & 85.9 \\
\hline 2 & Which of the following is true about washing/ sanitizing hands & 143 & 95.9 \\
\hline 3 & What are the symptoms of COVID-19 & 137 & 91.9 \\
\hline 4 & What are the safe guards from COVID-19 & 144 & 96.6 \\
\hline 5 & Which of the following is COVID-19 & 75 & 50.3 \\
\hline 6 & Which of the following is true about COVID-19 & 88 & 59.1 \\
\hline 7 & Which of the following steps can prevent infection & 135 & 90.6 \\
\hline 8 & Which age group are affected by COVID-19 & 114 & 76.5 \\
\hline 9 & What should you do if you have symptoms of COVID-19 & 105 & 70.4 \\
\hline 10 & Where should you throw your used mask and tissue paper & 140 & 93.9 \\
\hline 11 & The overall Knowledge regarding COVID-19 & - & - \\
\hline 12 & Good knowledge & 104 & 69.8 \\
\hline 13 & Average Knowledge & 43 & 28.9 \\
\hline 14 & Poor knowledge & 2 & 1.34 \\
\hline 15 & Knowledge towards COVID-19 (Mean \pm SD) & $8.18 \pm 1.28$ \\
\hline
\end{tabular}

Table No.3: Frequency and Percentage distribution of perception of COVID-19 among people living in and around Madurai $(\mathrm{N}=149)$

\begin{tabular}{|c|c|c|c|c|c|c|c|}
\hline \multirow{3}{*}{ S.No } & \multirow{3}{*}{ Items } & \multicolumn{2}{|c|}{ Agree } & \multicolumn{2}{|c|}{ Uncertain } & \multicolumn{2}{|c|}{ Disagree } \\
\hline & & \multicolumn{6}{|c|}{$(n=149)$} \\
\hline & & $\mathbf{F}$ & $\%$ & $\mathbf{F}$ & $\%$ & $\mathbf{F}$ & $\%$ \\
\hline 1 & I may get illness in this season & 27 & 18.1 & 56 & 37.5 & 66 & 44.2 \\
\hline 2 & $\begin{array}{l}\text { I am worried that one of my family members and } \\
\text { friends may get affected with this illness }\end{array}$ & 89 & 59.7 & 26 & 17.4 & 34 & 22.8 \\
\hline 3 & I like to isolate myself in hospital if I get COVID-19 & 121 & 81.2 & 10 & 6.71 & 18 & 12 \\
\hline 4 & I like to vaccinate if vaccines are available & 114 & 76.5 & 13 & 8.72 & 22 & 14.7 \\
\hline 5 & Perception of COVID-19 (Mean \pm SD) & \multicolumn{6}{|c|}{$2.35 \pm 0.91$} \\
\hline
\end{tabular}

Table No.4: Association of knowledge scores with selected demographic variables $(\mathrm{N}=149)$

\begin{tabular}{|c|c|c|c|c|c|}
\hline S.No & Demographic variables & Knowledge & Chi-square & $\mathbf{P}$ & Significance \\
\hline & Age in years & & \multirow{4}{*}{5.6801} & \multirow{4}{*}{.58424} & \multirow{4}{*}{ NS } \\
\hline 1 & 18 to 30 & $4.98 \pm 4.28$ & & & \\
\hline 2 & 31 to 50 & $2.57 \pm 3.77$ & & & \\
\hline 3 & $>51$ & $0.65 \pm 2.08$ & & & \\
\hline \multicolumn{3}{|c|}{ Gender } & \multirow{3}{*}{2.1396} & \multirow{3}{*}{.14354} & \multirow{3}{*}{ NS } \\
\hline 4 & Male & $1.87 \pm 3.41$ & & & \\
\hline 5 & Female & $6.30 \pm 3.70$ & & & \\
\hline \multicolumn{3}{|c|}{ Marital status } & \multirow{3}{*}{3.3032} & \multirow{3}{*}{.191745} & \multirow{3}{*}{ NS } \\
\hline 6 & Married & $3.74+4.08$ & & & \\
\hline 7 & Unmarried & $4.30 \pm 4.26$ & & & \\
\hline
\end{tabular}

Available online: www.uptodateresearchpublication.com March - April 
Rathi R K and Revathi R. / International Journal of Research in Pharmaceutical and Nano Sciences. 9(2), 2020, 39-45.

\begin{tabular}{|c|c|c|c|c|c|}
\hline 8 & Others (widowed) & $0.13 \pm 1.03$ & & & \\
\hline \multicolumn{3}{|c|}{ Education } & \multirow{5}{*}{13.6356} & \multirow{5}{*}{.003446} & \multirow{5}{*}{$\mathrm{S}$} \\
\hline 9 & Illiterate & $0.64 \pm 2.34$ & & & \\
\hline 10 & School education & $3.14 \pm 3.80$ & & & \\
\hline 11 & Undergraduate & $3.65 \pm 4.36$ & & & \\
\hline 12 & Postgraduate & $0.73 \pm 2.33$ & & & \\
\hline & Occupation & & \multirow{4}{*}{8.1147} & \multirow{4}{*}{.017038} & \multirow{4}{*}{$\mathrm{S}$} \\
\hline 13 & Unemployed & $2.04+3.57$ & & & \\
\hline 14 & Employed & $2.60 \pm 3.52$ & & & \\
\hline 15 & Students & $3.53 \pm 4.46$ & & & \\
\hline \multicolumn{3}{|c|}{ Source of COVID-19 information } & \multirow{4}{*}{15.8745} & \multirow{4}{*}{.000357} & \multirow{4}{*}{$\mathrm{S}$} \\
\hline 16 & Television & $4.26 \pm 4.11$ & & & \\
\hline 17 & Social media (WhatsApp, Facebook) & $3.55 \pm 4.30$ & & & \\
\hline 18 & Friends/relatives & $0.36 \pm 1.50$ & & & \\
\hline
\end{tabular}

*Significance at .05 level

NS -Non significant, S - Significant

Table No.5: Association of perception scores with selected demographic variables $(\mathrm{N}=149)$

\begin{tabular}{|c|c|c|c|c|c|}
\hline S.No & Demographic variables & Attitude & Chi-square & $\mathbf{P}$ & Significance \\
\hline & Age in years & & \multirow{4}{*}{8.3899} & \multirow{4}{*}{015071} & \multirow{4}{*}{$\mathrm{S}$} \\
\hline 1 & 18 to 30 & $1.40 \pm 1.46$ & & & \\
\hline 2 & 31 to 50 & $0.59 \pm 1.25$ & & & \\
\hline 3 & $>51$ & $0.18 \pm 0.60$ & & & \\
\hline & Gender & & \multirow{3}{*}{1.298} & \multirow{3}{*}{.254576} & \multirow{3}{*}{ NS } \\
\hline 4 & Male & $0.46 \pm 0.78$ & & & \\
\hline 5 & Female & $1.88 \pm 1.41$ & & & \\
\hline & Marital status & & \multirow{4}{*}{4.5763} & \multirow{4}{*}{.101452} & \multirow{4}{*}{ NS } \\
\hline 6 & Married & $1.08 \pm 1.25$ & & & \\
\hline 7 & Unmarried & $1.22 \pm 1.41$ & & & \\
\hline 8 & Others (widowed) & $0.04 \pm 0.34$ & & & \\
\hline & Education & & \multirow{5}{*}{0.3541} & \multirow{5}{*}{.949548} & \multirow{5}{*}{ NS } \\
\hline 9 & Illiterate & $0.19 \pm 0.72$ & & & \\
\hline 10 & School education & $0.80 \pm 1.10$ & & & \\
\hline 11 & Undergraduate & $1.12 \pm 1.74$ & & & \\
\hline 12 & Postgraduate & $0.23 \pm 0.76$ & & & \\
\hline \multicolumn{3}{|c|}{ Occupation } & \multirow{4}{*}{1.4601} & \multirow{4}{*}{.481884} & \multirow{4}{*}{ NS } \\
\hline 13 & Unemployed & $0.55 \pm 1.05$ & & & \\
\hline 14 & Employed & $0.75+1.14$ & & & \\
\hline 15 & Students & $1.04 \pm 1.41$ & & & \\
\hline \multicolumn{3}{|c|}{ Source of COVID-19 information } & \multirow{4}{*}{0.4892} & \multirow{4}{*}{.783001} & \multirow{4}{*}{ NS } \\
\hline 16 & Television & $1.28 \pm 1.36$ & & & \\
\hline 17 & Social media (WhatsApp, Facebook) & $0.97 \pm 1.31$ & & & \\
\hline 18 & Friends/relatives & $0.09 \pm 0.46$ & & & \\
\hline
\end{tabular}

*Significance at .05 levels

NS - Non significant, S - Significant

Available online: www.uptodateresearchpublication.com $\quad$ March - April 
Rathi $R$ K and Revathi R. / International Journal of Research in Pharmaceutical and Nano Sciences. 9(2), 2020, 39-45.

\section{CONCLUSION}

People had almost good knowledge about COVID19. Creating awareness through media will encourage and help them to develop optimistic attitudes and maintain safe practices. Hopefully our government efforts jointly make us to win the battle of COVID-19 in upcoming days.

\section{ACKNOWLEDGEMENT}

The authors wish to express their sincere gratitude to Velammal School and College of Nursing, Madurai, Tamil Nadu, India for providing necessary facilities to carry out this review work.

\section{CONFLICT OF INTEREST}

We declare that we have no conflict of interest.

\section{REFERENCES}

1. WHO, Coronavirus disease 2019 (COVID19), World Health Organization, 2020. [Online]. Available from: https://www.who.int/emergencies/diseases/n ovel-coronavirus-2019.

2. WHO, WHO Director-General's opening remarks at the mission briefing on COVID19, 2020, [Online]. Available from: https://www.who.int/dg/speeches/detail/who -director-general-s-opening-remarks-at-themission-briefing-on-covid-19.

3. Kumar D, Malviya R, Kumar Sharma P, Corona Virus: A Review of COVID-19, Eurasian Journal of Medicine and Oncology, 4(1), 2020, 8-25.

4. Akshaya Srikanth Bhagavathula, Wafa Ali Aldhaleei, Jamal Rahmani, Mohammad Javad Ashrafi Mahabadi. Novel Coronavirus (COVID-19) Knowledge and Perceptions: A Survey of Healthcare Workers, Med Rxiv, 2020, 1-15.
5. Deblina Roy, Sarvodaya Tripathy, Sujita Kumar Kar, Nivedita Sharma, Vikas Kaushal. Study of knowledge, attitude, anxiety and perceived mental healthcare need in Indian population during COVID-19 pandemic, Asian Journal of Psychiatry, 51, 2020, 102083.

6. Chan J F, To K K, Tse H, Jin D Y, Yuen K $\mathrm{Y}$. Interspecies transmission and emergence of novel viruses: lessons from bats and birds, Trends Microbiol, 21(10), 2013, 544555.

7. World Health Organization, Novel coronavirus (COVID-19) situation, Available online: https://experience.arcgis.com/experience/685d0 ace521648f8a5beeeee1b9125cd.

Please cite this article in press as: Rathi $\mathrm{R} \mathrm{K}$ and Revathi $\mathrm{R}$. Assessment of knowledge and perception towards COVID-19 among people living in and around Madurai, International Journal of Research in Pharmaceutical and Nano Sciences, 9(2), 2020, 39-45. 